\title{
ECOLOGICAL RISKS \\ IN THE ECONOMIC TRANSITION CONDITIONS: CASE STUDY OF REINDUSTRIALIZATION OF VALJEVO
}

\author{
Tijana Đorđević ${ }^{*_{1}}$ \\ "University of Belgrade - Faculty of Geography, Belgrade
}

\begin{abstract}
In this paper we presented the case study of reindustrialization of Valjevo - ecological risks in the conditions of economic transition. The crisis in Serbia during the 1990s had, among others, consequences visible in the manufacturing activities, especially industry. Nevertheless, Valjevo, as an evident example of favorable business environment, has made significant efforts to build an ambient for successful entrepreneurship. The aim of the paper is a critical presentation of the state of: economy and employment, processes of reindustrialization, environment and ecological risks in Valjevo. Special attention was given to the presentation of investment activities (direct investments recorded from companies from Austria, Italy, Slovenia, Croatia and other countries). The state of the environmental elements' quality has been estimated, and, on the basis of this, we can conclude that in Valjevo, it is mainly satisfactory, although, in some areas, more or less altered. Also, that a higher concentration of population and various economic activities, along with inherited industrial production (outdated technological processes, large quantities of industrial waste, low energy efficiency, lack of facilities and equipment for pollution reduction, etc.) are in conjunction with the possible occurrence of ecological risks. It was found that the current state of data and planning documents related to ecological risks assessment on the territory of Valjevo, is characterized by the basic availability of information on the dangers of possible natural disasters and technological accidents, as well as on severity of consequences that can cause (endangering the health, security and life of people, damage of a smaller or larger volume, changes of the environmental status,
\end{abstract}

${ }^{1}$ Corresponding author: T. Đorđević, University of Belgrade - Faculty of Geography, Studentski trg 3/III, 11,000 Belgrade, Serbia; e-mail: tdjordjevic@gef.bg.ac.rs 
etc.). In order to reduce the consequences of possible ecological risks and develop a sustainable and effective way of their management, it is necessary to take measures of prevention and protection, both of the population, and of natural and material goods. Also, investors, as well as local government in Valjevo, have to follow legal norms and standards and work on: introducing and encouraging of new technologies use and developing of socially responsible business with expert services and professional personnel trained to control and manage possible ecological risks.

Key words: Valjevo, reindustrialization, environment, ecological risks.

\section{Introduction}

Reindustrializiation is a process of structural change in industries, proceeds as a result of a need to reinvigorate national ecomomies. Therefore, economic growth is stimulated through government aid and tax incentives, modernization of factories and machinery, (foreign) direct investments etc. Its main feature is an increase in relative participation in the GDP creation and employment, particulary in these industrial branches in which technical and technological progress is the leading development factor. According to Dimitrijević et al. (2013) reindustrialization does not mean recovery of failed enterprises, but: expansion of financially "healthy“ (private and public) enterprises, revitalizing of public enterprises and restructuring companies that can contribute to the production gap elimination and the emergence and development of new enterprises based on modern technology platforms (in private and public sector). The issues of the processes of transition and reindustrialization were dealt with by numerous foreign (Dubenetskii, 2014; Gryczka, 2015; Göler \& Lehmeier, 2012; Młody, 2016; Russu, 2010), and domestic authors (Adžić, 2007; Milivojević, 2015; Mićić, 2015; Mićić \& Zeremski, 2011; Stevanović $i d r ., 2013)$ and many other.

Valjevo is the economic, cultural and administrative center of Valjevo region and the seat of the Kolubara Administrative District. According to the 2011 census data, in the city live 59,073 inhabitants, and in the municipality 90,312 (P3C, 2014) $)^{2}$. In administrative terms, city of Valjevo borders with municipalities of $\mathrm{Ub}$ and Koceljeva in the north, Osečina and Ljubovija in the west, Kosjerić and Požega in the south, and Mionica and Lajkovac in the east.

${ }^{2}$ Population growth in the 1948-2011 period (index 128.2) is slightly higher than the average for Central Serbia (index 126.5). In the same period, number of households increased from 15,037 to 31,500, and the average household has 2,9 members (P3C, 2014; 2014a). 
Industry of Valjevo began to develop after the end of the Second World War. However, the process of industrialization reached its peak in the late 1970s and early 1980s, which "caused“ urbanization of the city. The main industrial branch in Valjevo was metal processing, where in 1975 about $70 \%$ of the total number of employees in industrial activity were employed (Скупштина Општине Ваљево, 1976). Investments are an important indicator of the development of certain (economic) branches. In the development of this branch has been invested actively - by expanding existing capacities and by building new plants (until the 1990s). Investments in the industry of Valjevo amounted only $18.80 \%$ in total investments in the municipalities of the Kolubara District in 1991. Nevertheless, it has managed to remain an economic center of the District thanks to the (already) developed metal processing, food production and processing, machine and electrical industry.

During the mentioned period, and further, number of workers employed in industry and mining increased. Based on data from the 1971 census, the participation of employees in these sectors in the total (active) population of the municipality of Valjevo amounted to $16.73 \%$, and in $201121.72 \%$ (calculated on the basis of data: P3C, 2014b; C3C, 1974). Contrary to this increase, in the period from 1971 to 2011, a decrease of 30\% in the share of the population working in agriculture was recorded (on the Municipality level). That resulted in a smaller volume of investments in agriculture. This was the "consequence" of the development of Valjevo - in the district and administrative center, and the acquisition of new (tertiary and quadratic) functions. Over time, Valjevo has specialized in tertiary-quaternary activities that took over primacy in relation to secondary ${ }^{3}$ ones, and according to Матијевић (2005) it gained the role of a regional pole of concentration. Regional aspects of reindustrialization were the subject of research of many authors (Jucu, 2015; Kuleshov \& Seliverstov, 2016; Lončar \& Braičić, 2016; Ждан et al., 2016; Seliverstov, 2017; Wink et al., 2016) and others.

\section{Methodology and data}

This paper is structured for the purpose of examining and presenting the case study of reindustrialization of Valjevo - ecological risks in the conditions of economic transition - namely after the change of the political regime

${ }^{3}$ Spatial development of Valjevo has significantly influenced changes in population's activities. For example, mining lost its importance, and the priority was given to the traffic, trade, public services, health and social protection and education. 
in Serbia in 2000. Thus we tried to determine and give a critical examination of the: process of reindustrializiation and foreign direct investment inflows, recent state of economy (employment rates and types of the industries), and state of the environment and ecological risks in Valjevo during given period. In terms of methodology, the paper is based on an analysis of data obtained from Statistical office of Serbia (P3C). For a more comprehensive consideration of given issues, various local and regional data (from Department for local development and economy of the city of Valjevo (Odsek za lokalni razvoj i privredu) ) and publications (Local Environmental Action Plan of Valjevo (ЛЕАП), Spatial Plan of the Municipality of Valjevo (ППО Ваљево), General urban plan for the city of Valjevo (ГУП), General Regulation Plan for the Tourist Center Divčibare (План генералне регулације за туристички центар Дивчибаре), and Regional Spatial Plan for the Kolubara and Mačva District (РППП Колубарског и Мачванског УО)) and foreign sources (scientific papers and researches) were used.

\section{Recent state of the economy and employment}

The transformation from a socialist country and country-planned economy towards a western-style democracy and market based economy has caused dramatic changes in economic, social, ecological and spatial development in many post-socialist countries (Miljanović et al., 2010), as well as in Serbia. Like many other cities in Serbia, Valjevo faced difficulties of economic restructuring long-lasting process. The transition period caused immeasurable damage to the economy of Valjevo. The consequences of the privatization process (textile and furniture industries, cardboard packaging, and of large companies in the field of metal processing) are:

- the process of restructuring and privatization of almost all large state owned and social owned enterprises (which employed most of the labor force),

- increase in unemployment (7,800 persons or 89 per 1,000 inhabitants in 2015) (P3C, 2017) and

- low earnings of employees ${ }^{4}$.

${ }^{4}$ For example, the average amount of earnings excluding taxes and contributions per employee in Valjevo in 2011 was 32,010 dinars (rep. average - 37,976), in 2013 - 36,874 (rep. average - 43,932), and in 2015 - 37,886 (rep. average - 44,432 dinars), or about $15 \%$ less than the republic average (P3C, 2017). 
Present economy of Valjevo is characterized by metal processing industry with weapons production, production of electrical household appliances, ready-made clothing, primary agricultural production, construction and graphic industry. The total number of employees in Valjevo in 2015 was 25,999 ( $44.01 \%$ of the total population), i.e. 296 per 1,000 inhabitants. Data on the registered number of employees indicate a high share of employees in the social sector (companies, enterprises, institutions, cooperatives and other organizations) $-19,400$ or $74.62 \%$, private entrepreneurs (self-employed persons) and their employees $-4,719$ or $18.15 \%$ of the total number of employees, and $1.880(7.23 \%)$ were registered as individual farmers (based on data: P3C, 2017). By sectors of activity, the largest number of employees is recorded in: processing industry -8.253 , wholesale and retail trade (and repair of motor vehicles) -3.521 , health care and social protection sector -1.882 , education - 1.804, public administration (and mandatory social insurance) 1,627, construction $-1,314$ and transport (and storage) - 1,006 persons (P3C, 2017). Adaptability to the conditions of a market economy also recommends maximizing of existing capacities use, and organizing them in the conditions which are required by the modern society. Degree of the development success depends on the achieved level of dynamics and flexibility of all involved (state and local) stakeholders (Јеремић, 2013).

The base of the local economy consists of 5,675 enterprises (of which $96.73 \%$ are small, $2.74 \%$ medium and $0.53 \%$ large sized). The largest domestic companies are: Vujić doo, Agranela, Klanica Divci, INGRAP-OMNI, BOSIS and others (http://www.valjevo.rs/). Although Valjevo has begun to favor and stimulate the development of private sector (as well as small and medium-sized enterprises) a few decades ago, its overall effects on income and employment are still insufficient. Nevertheless, Valjevo also makes significant efforts to build an environment for successful operations and bringing investors, and is recognizable by a large number of investment locations. The General urban plan for the city of Valjevo (2013) provides of about 340 ha for two industrial zones - „Valjevo" and "Krušik" and economic zone „Beloševac".

\section{Processes of reindustrializiation}

Although the crisis in Serbia during the 1990s had consequences visible in the sphere of manufacturing activities, especially in the industry, Valjevo, as an evident example of favorable business environment, has made significant efforts to build an ambient for successful entrepreneurship. Also, 
it is worth to mention that on whole industry as well as the degree of industrialization, investments (domestic and foreign) have great impact. The accumulation (or lack) of investment activities in selected environments is the consequence of a number of factors where social economic differentiation in a region is reflected in changed location factors and where its advantages or disadvantages also contribute to the occurrence of new social and regional inequalities (Аничић $u$ дp., 2011; Ravbar, 2009).

Some of the reasons for investing in Valjevo are: favorable geographical position, good state of (communal, transportation...) infrastructure, already built manufacturing and infrastructural capacities, adequate age and educational structure of laboure force, a large number of investment sites, benefits for the development of agricultural production - availability of raw materials for the food processing industry, etc. Sectors and activities that are considered to be suitable for investments are: metal processing, electrical, food production and processing, IT, chemical, and textile industry, trade with financial services, and wood processing and construction. Therefore, interest of foreign investors (for example, Austrian "Austrotherm " ${ }^{5}$, Italian "Golden Lady" ${ }^{\prime \prime}$ and Slovenian "Gorenje ${ }^{\prime \prime 7}$ ) who build production facilities in Valjevo in past few years, is not surprising. Since 2012, there are two megamarkets in the city: "Roda market" of the Croatian concern "Agrokor" and "InterEX" owned by French "Intermarché" and the company "IDEA“ owned by the Croatian retailer "Konzum“. In April 2016, the retail park of the Austrian company "Immofinanz" began operating in Valjevo. The total value of the above investments is about 74 million $€$, with about 3,000 employees (Odsek za lokalni razvoj i privredu, 2016).

\footnotetext{
${ }^{5}$ Styrofoam's factory "Austrotherm", the first greenfield investment in Valjevo, started production in mid 2003. The total value of the investment in the industrial zone of Valjevo, on an area of $12,000 \mathrm{~m}^{2}$, is 6 million $€$, and the factory employs about 130 workers (Odsek za lokalni razvoj i privredu, 2016).

6 "Golden lady", the world-renowned manufacturer of socks and fine lingerie, in 2004 invested through greenfield investment in the Beloševac industrial zone by opening a "Valy" factory (at 10,000 $\mathrm{m}^{2}$ ) and employing about 1,500 employees (Odsek za lokalni razvoj i privredu, 2016).

${ }^{7}$ The industrial complex extends to about $50,000 \mathrm{~m}^{2}$ - the production hall and the distribution center were put into operation in 2006, and the second factory in 2013. The production capacity is about 1,000,000 refrigerating appliances annually. The total value of the investment is over 40 million $€$, with more than 1,000 employees (Odsek za lokalni razvoj i privredu, 2016).
} 


\section{State of the environment}

The basic factors of environmental quality state are: pollution of water, air and soil, area devastation and reduction of quality of life caused by economic activities, as well as pollution caused by absence of organized collection of solid municipal and hazardous waste, irrational and uncontrolled exploitation of mineral raw materials, uncontrolled and irregular use of agrochemicals in agriculture, and others. According to current data, the state of environment of Valjevo is altered - more or less poluted and degradated in some areas.

Valjevo conducts continuous monitoring of environmental quality parameters (e.g. $\operatorname{air}^{8}$ and water). In the other settlements of the Municipality permanent monitoring of the state of the media has not been established. Locations of the most important pollutants - industrial plants and exploitation sites of clay, Zn and Mn, can be classified as areas of polluted and degraded environment, while the industrial zone in Valjevo has been recognized as one of the most polluted sites (,hot spot") in the Kolubara District (РППП Колубарског и Мачванског УО, 2013).

Pollution of air, water, soil, ionizing radiation and noise are significantly caused by: activities in mining and metallurgy - Valjevo (along with Lazarevac and Tamnava) basin, exploitation of clay, industrial activities etc. Big pollution sorce (of air and soil) is road traffic in the city center and in the corridors of the state roads in Valjevo's surroundings, as well as the heating and household combustion. Also, the problem presents non adequate state of communal infrastructure, which is reflected in: inadequate disposal of waste - a large number of non-sanitary landfills ${ }^{9}$ and large quantities of wastewater from industry (and rural settlements ${ }^{10}$ ), which are being recruited without previous treatment into the rivers Kolubra, Gradac and other. However, a positive example is the water supply system of the city and other settlements of the Municipality. Valjevo water supply system has become one of the best waterworks in Serbia, after the construction of the new water treatment plant „Pećina“. After putting in operation of a new water purification plant at Divčibare and the introduction of reverse osmosis, the problem of water quality in this waterworks has been solved (ППО Ваљево, 2005).

\footnotetext{
${ }^{8}$ In Valjevo, systematic monitoring of air quality for measuring concentrations of main pollutants is performed.

${ }^{9}$ The largest unofficial landfills are located at the locations: Belo polje, Paune, Poćuta, Stave and Kunice (ЛЕАП, 2010).

${ }^{10}$ In Valjevo, which also has a quality sewage system („Gorić" $)$, wastewater is being purified (ЛЕАП, 2010; ППО Ваљево, 2005).
} 
The quality of water resources in the research area diverse. Watercourses of the Valjevo mountain range are without greater effluent loading and have excellent and very good status (class I and I / II). All watercourses in the city area, but also in the downstream Kolubara, by the data from Water management bases of the Republic of Serbia, have high quality class, although the real quality of the Kolubara is III / IV class. The quality of groundwater varies (particles of $\mathrm{Fe}, \mathrm{Mn}$ and $\mathrm{Zn}$ are present) (Odsek za lokaIni razvoj i privredu, 2016; РППП Колубарског и Мачванског УО, 2013).

Air quality depends on the level of pollutants from various sources of pollution. They can cause harmful effects on natural ecosystems and humah health when exceeding the permissible limit values. However, air quality is not significantly threatened, with the exception of the city area of Valjevo in the winter months (heating, household combustion). Also, Joksić et al. (2010) point out that as in other urban settlements in Serbia, the influence of $\mathrm{PM}_{10}$ (byproduct of industrial activities and emissions from road traffic, heating and resuspended dust) on the air quality state in Valjevo is high.

The area of Valjevo consists for the largest part (about 70\%) of I-IV quality class soils, which means that arable land is predominant. V-VIII quality class includes around 30\% and covers hilly and mountainous terrains (Odsek za lokalni razvoj i privredu, 2016). The soil is endangered by exploitation, industry and traffic. Valjevo region is extremely endangered by erosion, with occurrences of: heavy erosion (in the Kolubara basin), medium erosion (in the municipality of Valjevo) and week erosion on larger areas (РППП Колубарског и Мачванског УО, 2013).

The communal waste collection system covers $95 \%$ of the city population, and only a few rural settlements. From the aspect of citizens' security and risk management, it is necessary to emphasize that Valjevo has solved the problems of managing hazardous chemical and medical waste, but it has not solved the problem of disposal of slaughtering industry waste (Odsek za lokalni razvoj i privredu, 2016). In waste management sector, unofficial and old landfills and dumps are also a major problem, mostly in rural settlements that are not part of an organized waste collecting network.

The area of tourist and mountain resort Divčibare, due to negative anthropogenic activities is threatened with serious environmental damage. Expansion of construction during recent years requires an urgent solution of one the key problems - sewerage network. If nothing is done in the near future, there is a danger of deterioration of ground and surface water resources and soil quality, and other consequences (План генералне регулације за туристички центар Дивчибаре, 2008). 


\section{Ecological risks}

Risk represents a measure of a certain level of probability that some (natural or anthropogenic) activity or process, directly or indirectly, might cause a danger to the environment, human life and health, and other values. Risk assessment/analysis is a methodology used for determination the nature and extent of risk by analyzing potential hazards and evaluating existing conditions of vulnerability that could pose a potential threat or harm to people, property, livelihoods and the environment on which they depend (Rodier \& Norton, 1992; UNISDR, 2009).

Ecological risk can be defined as evaluation of the likelihood of environmental hazards that can lead to endangering humans, living world or ecosystems (US EPA, 1998). In this regard, the following activities should be pointed out: management of ecological risks - a complex process of collecting, organizing, analyzing and presenting scientific and other data, for the purpose of enacting and implementing decisions related to the protection and improvement of the state of the environment and the assessment of ecological risk - establishing the existence of a relationship between risk factors (stressors) and ecological effects (Bakrač $i d r ., 2012$ ). Brigagao (1990) emphasizes the importance of the influence of social (in)equity and local sustainable development on the state of (elements) of the environment and the occurrence of (ecological) risks. Same author highlights desirable activities such as: equality of rights over natural resources, prohibition of environmental aggression, exchange of information on (existing and possible) national and regional ecological risks, cooperation in emergency situations, establishing responsibility for environmental problems at the international level, as well as self-sufficient development.

In Valjevo, as potential ecological risks (from the occurrence of natural disasters) are recognized: hydrological (flood), lithospheric (earthquakes, landslides), atmospheric (hailstorm, drought) and biological (forest fires). The degree of vulnerability is different and depends on the type of disaster and the expected potential damage (endangering the health, security and life of people and material damage of a smaller or larger volume). These risks, according to Dragićević \& Filipović (2009) might have a significant and tragic impact on society, impair the normal ways of life, hinder the economic, cultural, and sometimes political conditions of life, and delay the development of local communities. In terms of preventive actions and measures, to reduce and limit impacts of this type of ecological risks, given problems have been identified: insufficiently developed civil protection system for assistance during natural disasters and catastrophic events, lack of early warning 
system, unsatisfactorily level of awareness and lack of the citizens' culture of security in terms of protection, rescue and disaster risk reduction, the lack of a state insurance system against emergencies and others.

Also, industrial production (both at national and regional (and local) levels) contributes to environmental pollution and the occurrence of ecological risks due to: obsolete technological processes, low volume of use of secondary raw materials, low energy efficiency, existence of large quantities of industrial waste, lack of simulative measures, as well as pollution abatement technologies and equipment (especially waste water treatment plants, exhaust gases and hazardous waste) to reduce pollution. In terms of ecological risks aspects in due to the specificity of industrial production in Valjevo (e.g. potential ecological risks of the integration of explosive substances into ammunition), the company „Krušik“, manufacturer of artillery and rocket ammunition, is distinguished. The greatest risks are the processes of casting and pressing explosive substances and emissions of the mixtures of amorphous explosives in the air in the process of ventilation of production facilities. Although rigorous military-control regulations are respected, the ventilation and control equipment is outdated and requires more frequent verification procedures. Also, particular problem in „Krušik“ are dispersed powders of $\mathrm{Al}, \mathrm{Mg}$ and other metals which are additives to pyrotechnical mixtures during the final integration of ammunition assemblies (Milinović $i d r$., 2008).

\section{Conclusion}

It can be concluded that during and after transitional period, both at national, as well as at regional and local levels, continuous work on the process of building a constructive framework for national security and environmental risk management, is necessary. Numerous contemporary risks and dangers (ecological, technological, technical, health and other) that the local communities face, as well as the particularity and sensitivity of the consequences they cause (environmental, social, material, health), impose the need for protection and security to become a priority and interest of the civil society sector.

The current state of data and planning documents regarding ecological risks occurrence on the territory of Valjevo, is characterized by the basic availability of information, both on the dangers of possible natural disasters and anthropogenic accidents, as well as on severity of consequences ${ }^{11}$. In or-

${ }^{11}$ More at: http:/ / geoliss.mre.gov.rs 
der to evaluate the spatial vulnerability degree (and the possibility of occurrence of ecological risks), it is necessary to create a vulnerability cadastre in function of spatial and urban planning, in the form of a list of points and zones of possible risks, probability of occurrence, extent of consequences, and and set protection priorities. Unfortunately, data suggest that there are insufficient capacities of local authorities, expert services and professional personnel trained for modern approach to managing ecological risks and inadequate (and in insufficient volume) monitoring of natural and anthropogenic processes that determine the occurrence of ecological risks in Valjevo.

In order to minimize the consequences of possible ecological risks and to develop a sustainable and effective way of managing them, it is required to undertake measures of prevention and protection, both of the population, as well as of natural and material goods. In this regard, at the local level, in Valjevo, the existence and operation (preventive ${ }^{12}$ and curative $\mathrm{e}^{13}$ ) of the Caritas office, a trained facilitator for assisting and supporting local communities in the design of ways to reduce risks and face possible natural disasters, should also be emphasized.

Also, it is essential that investors, as well as local government in Valjevo, follow legal norms and standards ${ }^{14}$ and realize the importance of using new technologies that can provide better quality of the environment in the city and its surroundings and prevention of ecological risks. This refers to: affirmation of the use of renewable energy sources ${ }^{15}$, preservation of

12 These activities include: forming groups of volunteers, their training, proposing the main stages of the project, monitoring the group during the process of planning activities and providing support to local authorities. Also, education of elementary school pupils about proper behavior during emergency situations (http://caritas-valjevo.rs).

${ }^{13}$ Through diverse activities during the floods that affected Valjevo in 2002 and 2014, Caritas was involved from the very beginning in the care and provision of emergency assistance to vulnerable households (http:/ / caritas-valjevo.rs).

${ }^{14}$ For example, the Law on Environmental Protection, the Law on Environmental Impact Assessment, and the Law on Chemicals (include provisions on accident risk assessment and accident prevention planning, as well as other provisions in accordance with the requirements of the Seveso Directive), as well as the National Sustainable Development Strategy, the National Security Strategy of the RS and the National Strategy for Disaster Risk Reduction and Protection and Rescue in Emergencies.

${ }^{15}$ Renewable energy resources are a significant potential of Valjevo. For example, there are 13 locations at which construction of small hydro power plants has been planned. Also, there is a significant potential for the use of solar energy (the average daily amount of solar radiation energy in the city area is about $3.8 \mathrm{kWh} / \mathrm{m} /$ day, or an average of about 1,400 $\mathrm{kWh} / \mathrm{m} /$ year) (Odsek za lokalni razvoj i privredu, 2016a). 
the water and air quality, modernization of the waste management system (recycling, purification, etc.), development of databases and information systems, as well as monitoring of the state of the environment, introduction of environmentally friendly and best available technologies in production, transport, energy, etc. In order to achieve these priorities in the forthcoming period, the activities should focus on socially responsible business, establishing better links between science, technology and entrepreneurship, and raising the level of awareness of all stakeholders on the importance of ecological risks manage and control.

\section{Acknowledgements}

The paper is the result of the research within the project no. 176008 funded by the Ministry of Education and Science of the Republic of Serbia.

\section{References}

Adžić S. (2007). Reindustrijalizacija kao osnova strategije razvoja Srbije. Ekonomski vidici, 12(3), 387-401.

Bakrač T. S., Vuruna M. M. \& Milanović M. M. (2012). Metodologija upravljanja ekološkim rizikom i procene rizika. Vojnotehnički glasnik, 60(2), 296-305.

Brigagao C. (1990). Amazon and Antarctic: A New Look at Ecological Security. Peace Research, 43-49.

Göler D. \& Lehmeier H. (2012). From post-socialist transition to globalisation and europeanisation?: Metropolitan developments in Belgrade, Bucharest and Sofia. Zbornik radova-Geografski fakultet Univerziteta u Beogradu, 60, 33-48.

Dimitrijević B., Đuričin D., Đurić D., Grujić B., Perčević G. \& Spasojević T. (2013). Nacrt strategije reindustrijalizacije Srbije, Radna grupa za reindustrijalizaciju Nacionalnog saveta za privredni oporavak Vlade Srbije.

Dragićević S. \& Filipović D. (2009). Prirodni uslovi i nepogode u planiranju i zaštiti prostora. Geografski fakultet, Beograd.

Dubenetskii Y. N. (2014). Reindustrialization: Conditions, goals, and stages. Studies on Russian Economic Development, 25(4), 329-334.

Gryczka M. (2015). The Process of Reindustrialisation and Changes in Competitiveness of Selected Countries. Trends in the World Economy, 7, 39-52. 
Joksić J., Radenković M., Cvetković A., Matić-Besarović S., Jovašević-Stojanović M., Bartonova E. \& Yttri K. E. (2010). Variations of PM $_{10}$ mass concentrations and correlations with other pollutants in Belgrade urban area. Chemical Industry and Chemical Engineering Quarterly, 16(3), 251-258.

Jucu I. S. (2015). Romanian Post-socialist Industrial Restructuring at the Local Scale: Evidence of Simultaneous Processes of De-/Reindustrialization in the Lugoj Municipality of Romania. Journal of Balkan and Near Eastern Studies, 17(4), 408-426.

Kuleshov V. V. \& Seliverstov V. E. (2016). Program for reindustrialization of the Novosibirsk Oblast Economy: Development ideology and main directions of implementation. Regional Research of Russia, 6(3), 214-226.

Lončar J. \& Braičić Z. (2016). Industrial restructuring and downsizing: Case study of Central Croatia. Acta geographica Slovenica, 56(2), 209-220.

Mićić V. \& Zeremski A. V. (2011). Deindustrijalizacija i reindustrijalizacija privrede Srbije. Industrija, 39(2), 51-68.

Mićić V. (2015). Reindustrialization and structural change in function of the economic development of the Republic of Serbia. Ekonomski horizonti, 17(1), 15-31.

Milinović M., Lukić M. \& Jeremić O. (2008). Ekološki rizici odbrambene industrije Republike Srbije. CME (OEBS), Beograd.

Milivojević S. (2015). Reindustijalizacija Srbije u cilju jačanja srpske privrede. U: Stošić I. (ed.) „Strukturne promene u Srbiji - dosadašnji rezultati i perspektive“. Institut ekonomskih nauka, Beograd.

Miljanović D., Miletić R. \& Đorđević J. (2010). Regional inequality in Serbia as a development problem. Acta geographica Slovenica, 50(2), 253-275.

Młody M. (2016). Reindustrialization of the European Union member states in the context of reshoring. International Business and Global Economy, 35(1), 455-467.

Odsek za lokalni razvoj i privredu (2016). Profil grada Valjeva, Valjevo.

Odsek za lokalni razvoj i privredu (2016a). Dolina mogućnosti, Valjevo.

Official Gazette of RS, No. 101/15. (2015). Law on Mining and Geological Exploration.

Ravbar M. (2009). Economic geographical assessment of Investments - A development factor in regional development. Acta geographica Slovenica, 49(1), 143-178. 
Rodier D. \& Norton S. (1992). Framework for ecological risk assessment. Environmental Protection Agency, Washington, DC. Risk Assessment Forum.

Russu C. (2010). Getting out of the Crisis by Reindustrialization and a New Strategy of Romania's Economic Development. Petroleum-Gas University of Ploiesti Bulletin, Economic Sciences Series.

Seliverstov V. E. (2017). Development of the Program for Reindustrialization of the Economy of the Novosibirsk Oblast: Primary Outcomes. Problems of Economic Transition, 59(5), 375-397.

Stevanović S., Milanović M. \& Milacić S. (2013). Problems of the deindustrialization of the Serbian economy. Ekonomika poljoprivrede, 60(3), 465-477.

UNISDR (2009). UNISDR Terminology for Disaster Risk Redution. United Nations International Strategy for Disaster Reduction (UNISDR) Geneva, Switzerland.

US EPA (1998). Guidelines for ecological risk assessment. Risk Assessment Forum. US Environmental Protection Agency, Washington D.C., EPA/630/R-95/002F.

Wink R., Kirchner L., Koch F. \& Speda D. (2016). There are many roads to reindustrialization and resilience: Place-based approaches in three German urban regions. European Planning Studies, 24(3), 463-488.

Аничић Ј., Лакета М. \& Вукотић С. (2011). Инвестициона политика и регионални развој Србије у транзиционом периоду. Зборник Географског института "Јован Цвијић" - САНУ, 61(3), 47-61.

ГУП - Генерални урбанистички план Ваљева (2013). Службени гласник града Ваљева бр. 5/13. ЈП „Дирекција за урбанизам, грађевинско земљиште, путеве и изградњу Ваљево“, Ваљево.

Ждан Г. В., Щетинина И. В. \& Воронов Ю. П. (2016). Реиндустриализация экономики сельских территорий (на примере Новосибирской области). Регион: Экономика и Социиология, 4, 87-112.

Јеремић Д. (2013). Ваљево центар западне Србије. ЈП „Дирекција за урбанизам, грађевинско земљиште, путеве и изградњу Ваљево“, Ваљево.

ЛЕАП - Локални еколошки акциони план општине Ваљево (2010). Службени гласник града Ваљева бр. 8/10, Ваљево.

Матијевић Д. (2005). Урбано-географски процеси у мрежи насеља општине Љиг. Гласник Српског географског друштва, 85(2). 
План генералне регулације за туристички центар Дивчибаре (2008). Институт за архитектуру и урбанизам Србије и Дирекција за урбанизам, грађевинско земљиште и изградњу Ваљева, Ваљево.

ППО Ваљево - Просторни план општине Ваљево (2005). Институт за архитектуру и урбанизам Србије. Стратегија развоја, унапређења и коришћења простора, Београд.

РЗС (2014). Попис становништва 2011 - књига 20, Упоредни преглед броја становника 1948 - 2011. Републички завод за статистику, Београд.

Р3С (2014а). Попис становништва 2011 - књига 21, Упоредни преглед броја домаћинстава 1948 - 2011. и станова 1971 - 2011. Републички завод за статистику, Београд.

РЗС (2014б). Попис становништва 2011 - књига 15, Делатност. Републички завод за статистику, Београд.

Р3С (2017). Општине и региони у Републици Србији (исправљено издање). Републички завод за статистику, Београд.

РППП Колубарског и Мачванског УО - Регионални просторни план за подручје Колубарског и Мачванског управног округа (2013). Институт за архитектуру и урбанизам Србије и Јавно урбанистичко предузеће „План“", Београд/Шабац.

СЗС (1974). Попис становништва и станова 1971 - Пољопривредно становништво, резултати по насељима и општинама. Савезни завод за статистику, Београд.

Скупштина Општине Ваљево (1976). Предлог друштвеног плана Општине Ваљево за период 1976-1980. године. Записник са заједничке седнице Општег сабора Скупштине општине Ваљево од 03.12.1976. године, Ваљево.

http:// caritas-valjevo.rs

http://geoliss.mre.gov.rs

http://www.valjevo.rs/ 